\title{
PENGARUH PEMBERIAN EKSTRAK AIR ROSELLA (Hibiscus sabdariffa L) TERENKAPSULASI MALTODEXTRIN TERHADAP PEROKSIDASI LIPID HATI DAN GINJAL TIKUS WISTAR JANTAN YANG DIINDUKSI ISONIAZID-RIFAMPISIN
}

\author{
Jumasni Adnan, Yulia Yusrini Djabir, Mufidah, Sartini \\ Fakultas Farmasi, Universitas Hasanuddin, Makassar
}

Kata Kunci :

Ekstrak Rosella, Isoniazid-Rifampisin, Peroksidasi lipid, Malondialdehid

\begin{abstract}
ABSTRAK
Isoniazid dan rifampisin merupakan obat lini pertama antituberkulosis, namun kombinasi dari keduanya dapat meningkatkan resiko toksisitas pada hati dan ginjal. Kelopak bunga Rosella memiliki kandungan senyawa antioksidan yang dapat bersifat sitoprotektif. Tujuan dari penelitian ini adalah untuk mengevaluasi efek protektif ekstrak air bunga rosella terenkapsulasi maltodextrin terhadap peroksidasi lipid organ hati dan ginjal tikus jantan yang diinduksi isoniazid-rifampisin dosis toksik melalui pemeriksaan kadar malondialdehid (MDA). Sebanyak 25 ekor tikus wistar jantan dibagi ke dalam 5 kelompok. Kelompok I merupakan kontrol sehat, kelompok II diberi penginduksi isoniazid-rifampisin dosis toksik (50 mg/kg dan $100 \mathrm{mg} / \mathrm{kg}$ ), kelompok III diberi isoniazid-rifampisin dan ekstrak rosella 62.5 $\mathrm{mg} / \mathrm{kgBB}$, kelompok IV diberi isoniazid-rifampisin dan ekstrak rosella $125 \mathrm{mg} / \mathrm{kgBB}$, dan kelompok V diberi isoniaid-rifampisin dan ekstrak rosella $250 \mathrm{mg} / \mathrm{kgBB}$. Tikus diberi ekstrak Rosella secara peroral 4 jam sebelum induksi isoniazid-rifampisin. Setelah 35 hari perlakuan, tikus dieutanasia dan dilakukan pemeriksaan MDA organ hati dan ginjal menggunakan spektrofotometer UV-Vis. Pemberian isoniazidrifampisin dosis toksik selama 35 hari mampu meningkatkan MDA hati dan MDA ginjal lebih dari 3x lipat MDA hati tikus kontrol $(\mathrm{p}<0.01)$. Sedangkan, pemberian perlakuan ekstrak Rosella dosis $62.5 \mathrm{mg} / \mathrm{kgBB}$, $125 \mathrm{mg} / \mathrm{kgBB}, 250 \mathrm{mg} / \mathrm{kgBB}$ mampu mempertahankan kadar MDA hati dan ginjal tikus setara dengan kontrol sehat. Dapat disimpulkan bahwa ekstrak rosella terenkapsulasi maltodextrin mampu mencegah peningkatan aktivitas peroksidasi lipid hati dan ginjal tikus yang diinduksi isoniazid-rifampisin pada dosis $62.5 \mathrm{mg} / \mathrm{kgBB}, 125 \mathrm{mg} / \mathrm{kgBB}$, dan $250 \mathrm{mg} / \mathrm{kgBB}$.
\end{abstract}

\section{PENDAHULUAN}

Berdasarkan studi epidemiologi, salah satu obat penyebab kerusakan hati dengan kasus terbanyak adalah antituberkulosis (1). Beberapa studi menemukan insiden hepatotoksisitas terbilang tinggi mulai $13 \%$ hingga $31 \%$ pada pasien yang diobati dengan antituberkulosis (2,3). Hepatotoksistas dapat muncul setelah 2 minggu penggunaan obat antituberkulosis, tergantung pada kerentanan seseorang $(2,4)$.

Rifampisin dan isoniazid merupakan obat antituberkulosis lini pertama namun juga merupakan senyawa hepatotoksik yang paling potensial. Bahkan, kombinasi keduanya dapat meningkatkan efek toksik masing-masing obat (5). Mekanisme toksisitas isoniazid terjadi melalui pembentukan metabolit reaktif. Isoniazid dimetabolisme melalui reaksi asetilasi menjadi asetil isoniazid kemudian dihidrolisis menjadi asam isonikotinat. Asam isonikotinat kemudian dikonjugasi menjadi isonikotil glisin. Selain itu, asetil isoniazid juga dapat langsung diasetilasi menjadi $\mathrm{N}$-asetilhidrasin yang bersifat toksik (6).

Berbeda dengan isoniazid, mekanisme hepatotoksik rifampisin masih belum diketahui dengan pasti, tetapi rifampisin diketahui bekerja memodulasi enzim sitokrom P450 khususnya CYP2E1, sehingga dapat meningkatkan metabolisme isoniazid menjadi asam isonikotinat dan asetilhidrasin (7). Waktu paroh asetilhidrasin (AcHz) diperpendek oleh rifampisin dan $\mathrm{AcHz}$ dengan cepat diubah menjadi metabolit aktifnya dengan meningkatkan eliminasi oksidatif dari AcHz. Hal ini menyebabkan tingginya kejadian nekrosis hati yang disebabkan oleh isoniazid dan rifampisin dalam kombinasi. Bahkan, isoniazid dapat menghambat aktivitas enzim CYP1A2 yang terlibat dalam detoksifikasi hidrasin sehingga bisa menginduksi toksisitasnya sendiri $(8,9)$.

Selain menginduksi kerusakan hati, rifampisin juga ditemukan mampu menyebabkan kerusakan ginjal (10). Kerusakan hati dan ginjal akibat isoniazid dan rifampisin erat hubungannya dengan terjadinya stress oksidatif. Penelitian sebelumnya telah menunjukkkan terjadinya peningkatan oksidatif stress pada mitokondria sel ginjal dan hati tikus yang diberi isoniazidrifampisin $(11,12)$.

Meningkatnya kasus hepatotoksisitas dan nefrotoksisitas dari berbagai senyawa bioaktif memicu pencarian senyawa atau bahan yang bersifat protektif terhadap sel. Rosella (Hibiscus sabdariffa L.) merupakan salah satu tanaman obat yang memiliki aktifitas antioksidan dan telah diteliti mampu melindungi kerusakan hati pada tikus yang diberi CCl4 (13). Komponen utama pada bunga rosella adalah polifenol, antosianin, dan asam protokatekuat yang ditemukan pada ekstrak air kelopak bunga. Senyawa-senyawa tersebut diketahui efektif mengurangi stres oksidatif pada 
studi in vitro maupun in vivo $(13,14)$.

Telah dilaporkan bahwa $\mathrm{LD}_{50}$ ekstrak air rosella pada tikus adalah $>5000 \mathrm{mg} / \mathrm{kgBB}$, dan pemberian pada dosis 1000 $\mathrm{mg} / \mathrm{kgBB}$ menyebabkan kematian spontan pada tikus model hipertensi (15) sedangkan dosis $2000 \mathrm{mg} / \mathrm{kg}$ menyebabkan hewan uji mengalami diare (16). Sedangkan, LD50 ekstrak rosella terenkapsulasi maltodekstrin memiliki $L_{50}$ sebesar $20.000 \mathrm{mg} / \mathrm{KgBB}$ sehingga aman untuk digunakan (17) Maltodekstrin memiliki berbagai macam keunggulan digunakan sebagai bahan enkapsulasi, maltodekstrin merupakan serbuk dengan densitas yang rendah, tidak mudah caking, rasa lebih baik, pembentukan film dan ikatan, dan pembawa oksigen (18).

Oleh karena itu, penelitian ini bertujuan untuk mengevaluasi efek protektif ekstrak air bunga rosella terenkapsulasi maltodextrin terhadap peningkatan stress oksidatif hati dan ginjal pada tikus yang diinduksi obat anti-tuberkulosis isoniazid-rifampisin melalui pemeriksaan kadar MDA.

\section{METODE PENELITIAN}

\section{Alat dan Bahan}

Alat-alat yang digunakan adalah alat-alat gelas yang biasa digunakan di laboratorium, freeze dryer, humalyzer dan spektrofotometer UV-Vis.

Bahan yang digunakan adalah aquadest, alkohol, ekstrak air rosella, asam tiobarbiturat (TBA), asam trikloroasetat (TCA), dan 1,1,3,3-trimetoksipropana (TMP), maltodextrin, natrium $\mathrm{CMC}$, isoniazid dan rifampisin.

\section{Prosedur Kerja}

\section{Penyiapan Sampel Penelitian}

Sampel berupa simplisia kelopak bunga rosella (Hibiscus sabdariffa L.) yang diperoleh dari lingkungan Fakultas Farmasi Universitas Hasanuddin. Simplisia bunga rosella yang diperoleh disortasi untuk memisahkan dari pengotor. Simplisia bunga rosella lalu dicuci dengan air mengalir. Setelah kering diblender menjadi serbuk kasar kemudian dibuat infus $25 \%$.

\section{Penyiapan Sediaan Uji}

Pembuatan Larutan Koloidal Natrium CMC 1\%

Sebanyak 1 gram natrium CMC dimasukkan sedikit demi sedikit ke dalam $50 \mathrm{ml}$ air suling panas (suhu $70^{\circ} \mathrm{C}$ ) sambil diaduk dengan pengaduk elektrik hingga terbentuk larutan koloidal lalu dicukupkan volumenya dengan air suling dalam labu tentukur $100 \mathrm{ml}$.

\section{Pembuatan Suspensi Rifampisin dan Isoniazid}

Dosis yang digunakan untuk menginduksi hewan uji adalah Rifampisin $100 \mathrm{mg} / \mathrm{kg}$ dan Isoniazid $50 \mathrm{mg} / \mathrm{kg}$. Serbuk rifampisin dan isoniazid sebanyak $1000 \mathrm{mg}$ dan $500 \mathrm{mg}$ masing-masing disuspensikan ke dalam $100 \mathrm{ml}$ Natrium CMC $1 \%$ sehingga diperoleh suspensi yang mengandung $20 \mathrm{mg}$ rifampisin dan $10 \mathrm{mg}$ isoniazid dalam $1 \mathrm{ml}$ suspensi.

\section{Penyiapan Serbuk Terenkapsulasi}

Sebanyak $25 \mathrm{~g}$ simplisia bunga rosella yang diserbukkan dan dimasukkan ke dalam panci, kemudian dibasahi dengan air suling 4 kali bobot sampel (100 ml). Selanjutnya ditambah $100 \mathrm{ml}$ air suling dan dipanaskan di atas tangas air pada suhu $90^{\circ} \mathrm{C}$ selama 15 menit sambil sesekali diaduk, lalu diserkai selagi panas melalui kain flannel. Setelah disaring, dicukupkan volume hingga $100 \mathrm{ml}$. Cairan infus yang telah disaring ditambahkan dengan 2,5 gram maltodekstrin lalu dikeringkan dengan menggunakan freeze dryer hingga menjadi serbuk rosella terenkapsulasi maltodekstrin.
Pembuatan Larutan Sediaan Rosella Terenkapsulasi Larutan ekstrak air bunga rosella terenkapsulasi maltodextrin dibuat untuk 3 variasi dosis: (1) Dosis 62,5 $\mathrm{mg} / \mathrm{KgBB}$ dibuat dengan menimbang ekstrak air bunga rosella terenkapsulasi maltodekstrin sebanyak $312,5 \mathrm{mg}$ kemudian dilarutkan dengan aquadest sebanyak $25 \mathrm{ml}$, sehingga dalam larutan 0,5 ml mengandung 6,25 mg ekstrak air bunga rosella terenkapsulasi maltodekstrin. (2) Dosis 125 $\mathrm{mg} / \mathrm{KgBB}$ dibuat dengan menimbang ekstrak air bunga rosella terenkapsulasi maltodekstrin sebanyak $625 \mathrm{mg}$ kemudian dilarutkan dengan aquadest sebanyak $25 \mathrm{ml}$, sehingga dalam larutan $0,5 \mathrm{ml}$ mengandung $12,5 \mathrm{mg}$ ekstrak air bunga rosella terenkapsulasi maltodekstrin. (3) Dosis 250 $\mathrm{mg} / \mathrm{KgBB}$ dibuat dengan menimbang ekstrak air bunga rosella terenkapsulasi maltodekstrin sebanyak $1250 \mathrm{mg}$ kemudian dilarutkan dengan aquadest sebanyak $25 \mathrm{ml}$, sehingga dalam larutan 0,5 ml mengandung $25 \mathrm{mg}$ ekstrak air bunga rosella terenkapsulasi maltodekstrin.

\section{Prosedur Perlakuan}

Penanganan Hewan Uji

Sebanyak 25 ekor tikus jantan wistar dibagi dalam 5 kelompok perlakuan. Tiap kelompok terdiri dari 5 ekor tikus jantan wistar dan diberikan perlakuan selama 35 hari. Adapun 5 kelompok tersebut yaitu: (1) Kelompok I: Kontrol sehat (pembawa); (2) Kelompok II: Kontrol negatif (isoniazid + rifampisin); (3) Kelompok III: Perlakuan ekstrak air bunga rosella terenkapsulasi maltodextrin $62,5 \mathrm{mg} / \mathrm{KgBB}$, setelah 3 jam kemudian diberikan (isoniazid + rifampisin) ; (4) Kelompok IV: Perlakuan ekstrak air bunga rosella terenkapsulasi maltodextrin $125 \mathrm{mg} / \mathrm{KgBB}$, setelah 3 jam kemudian diberikan (isoniazid + rifampisin) ; (5) Kelompok V: Perlakuan ekstrak air bunga rosella terenkapsulasi maltodextrin $250 \mathrm{mg} / \mathrm{KgBB}$, setelah 3 jam kemudian diberikan (isoniazid + rifampisin)

Dosis isoniazid yang digunakan $50 \mathrm{mg} / \mathrm{KgBB}$ dan rifampisin $100 \mathrm{mg} / \mathrm{KgBB}$ selama 28 hari kemudian dosis dinaikkan dua kali menjadi $100 \mathrm{mg} / \mathrm{kgBB}$ isoniazid dan $200 \mathrm{mg} / \mathrm{kgBB}$ rifampisin hingga hari ke-35.

\section{Pemeriksaan MDA}

Pengambilan Organ Hati

Pada hari ke- 36 hewan uji dieutanasia dengan cara anastesi menggunakan eter. Tikus dibedah dan diambil organ hati dan ginjal kemudian dimasukkan dalam wadah berisi nitrogen cair hingga beku, disimpan pada lemari pendingin pada suhu $-20^{\circ} \mathrm{C}$ sampai digunakan untuk analisa.

\section{Pengukuran Kurva Baku}

Larutan baku yang digunakan dalam mengukur kadar peroksidasi lipid adalah baku diagnostik MDA yaitu 1,1,3,3tetrametoksipropana (TMP). Larutan baku dibuat dengan menggunakan larutan stock $1 \mathrm{ml}$ TMP yang dilarutkan dalam $10 \mathrm{ml}$ PBS (Phosphate buffer saline). Dibuat 6 variasi pengenceran yaitu 0,$05 ; 0,1 ; 0,15 ; 0,2 ; 0,25$ dan $0,3 \mathrm{ppm}$. Kemudian diukur absorbansinya pada panjang gelombang $532 \mathrm{~nm}$.

\section{Pemeriksaan MDA}

Salah satu cara mengetahui aktivitas peroksidasi lipid adalah mengukur kadar malondyaldehid (MDA) menggunakan metode thiobarbituric acid reactive substance (TBARS). Organ hati maupun ginjal digerus dan ditimbang sebanyak $400 \mathrm{mg}$ dan ditambahkan PBS pH 7,4 sebanyak $2 \mathrm{ml} \mathrm{ke} \mathrm{dalam}$ lumpang dan dicampur hingga homogen lalu disentrifus dengan kecepatan 3000 rpm selama 20 menit. Supernatan yang terbentuk dipipet sebanyak $0,5 \mathrm{ml}$ kemudian ditambahkan $1 \mathrm{ml}$ campuran TBA 1\% dan TCA 1\% kedalam tabung dan dipanaskan didalam tangas air pada suhu $95^{\circ} \mathrm{C}$ selama 50 menit dan didinginkan pada suhu kamar. Sampel disentrifus kembali dengan kecepatan 3000 rpm selama 10 
menit, kemudian dipipet supernatannya dan diukur kadar MDA dengan spektrofotometer UV-Vis pada panjang gelombang $532 \mathrm{~nm}$.

\section{Pengolahan dan Analisis Data}

Data disajikan dalam bentuk rerata \pm standar error mean. Data diolah dengan program komputer SPSS 22. Kadar MDA pada organ hati dan ginjal diperoleh distribusi data yang tidak normal sehingga dianalisis dengan uji Kruskal-Wallis dan dilanjutkan dengan uji Mann U Whitney untuk melihat perbedaan signifikan antar kelompok.

\section{HASIL DAN PEMBAHASAN}

Kelopak bunga rosella mengandung berbagai senyawa bioaktif yang telah dilaporkan memiliki efek hepatoprotektor dan nefroprotektor (19-21). Bahkan, ekstrak air rosella (100, 200 dan $300 \mathrm{mg} / \mathrm{kgBB}$ ) menunjukkan aktivitas hepatoprotektif pada tikus dengan meningkatkan kadar glutathione, katalase dan menurunkan kadar peroksidasi lipid $(15,22)$.

Dalam penelitian ini isoniazid-rifampisin digunakan sebagai penginduksi hepatotoksisitas dan nefrotoksisitas, karena isoniazid-rifampisin merupakan salah obat penyebab kerusakan hati terbanyak dalam berbagai kasus klinik (23). Dari pemeriksaan MDA hati dan ginjal ditemukan bahwa penggunaan isoniazid-rifampisin dengan dosis 50 dan 100 $\mathrm{mg} / \mathrm{kg}$ hingga 28 hari dilanjutkan dengan dosis 100 dan 200 $\mathrm{mg} / \mathrm{kg}$ hingga 35 hari mampu meningkatkan kadar MDA hati dan ginjal $>3$ kali lipat kadar MDA hati dan ginjal tikus sehat. Hasil uji Kruskal-Wallis menunjukkan bahwa kadar MDA di hati dan ginjal kelompok II berbeda sangat signifikan dengan kelompok I yang merupakan control sehat $(p<0.01)$. Hal ini menunjukkan terjadinya peningkatan aktivitas peroksidasi lipid pada jaringan hati dan ginjal tikus setelah pemberian isoniazid-rifampicin. Peroksidasi lipid merupakan aktivitas pembentukan peroksida (radikal bebas) pada lipid, utamanya pada membran sel dan membran mitokondria, sehingga mengganggu integritas sel maupun mitokondria (24). Hal ini akan memicu terjadinya kerusakan sel bahkan kematian sel. Peningkatan aktivitas peroksidasi lipid dapat diukur menggunakan parameter kadar Malondialdehid sebagai metabolit akhir dari peroksidasi lipid (25).

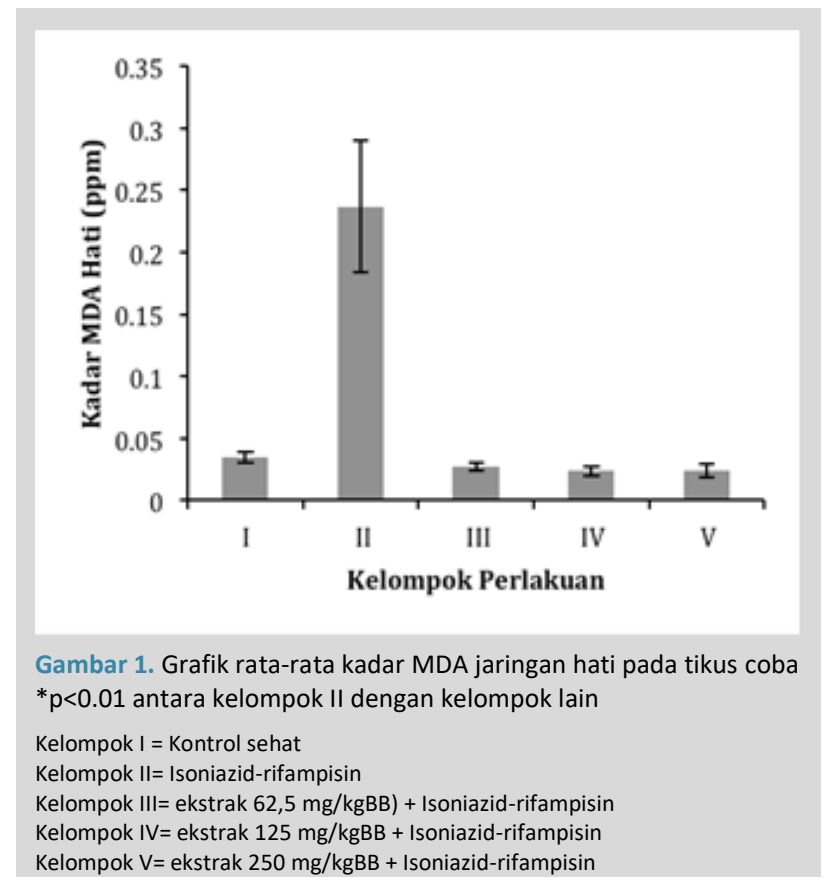

Hasil pemeriksaan kadar MDA pada organ hati dan ginjal dengan pemberian ekstrak air bunga rosella pada tikus ternyata mampu mencegah terjadinya peningkatan MDA pada jaringan hati maupun ginjal walaupun tikus diinduksi dengan isoniazid-rifampisin dosis toksik. Bahkan kadar MDA hati dan ginjal kelompok perlakuan ekstrak air Rosella hamper menyerupai kelompok kontrol sehat (gambar 1 dan 2). Hasil uji statistik menunjukkan bahwa kadar MDA di hati dan ginjal kelompok kontrol sehat tidak berbeda signifikan dengan kelompok III, IV dan V yang diberikan ekstrak air Rosella dosis 62,5 mg/kg, $125 \mathrm{mg} / \mathrm{kg}$ dan $250 \mathrm{mg} / \mathrm{kg}$ ).

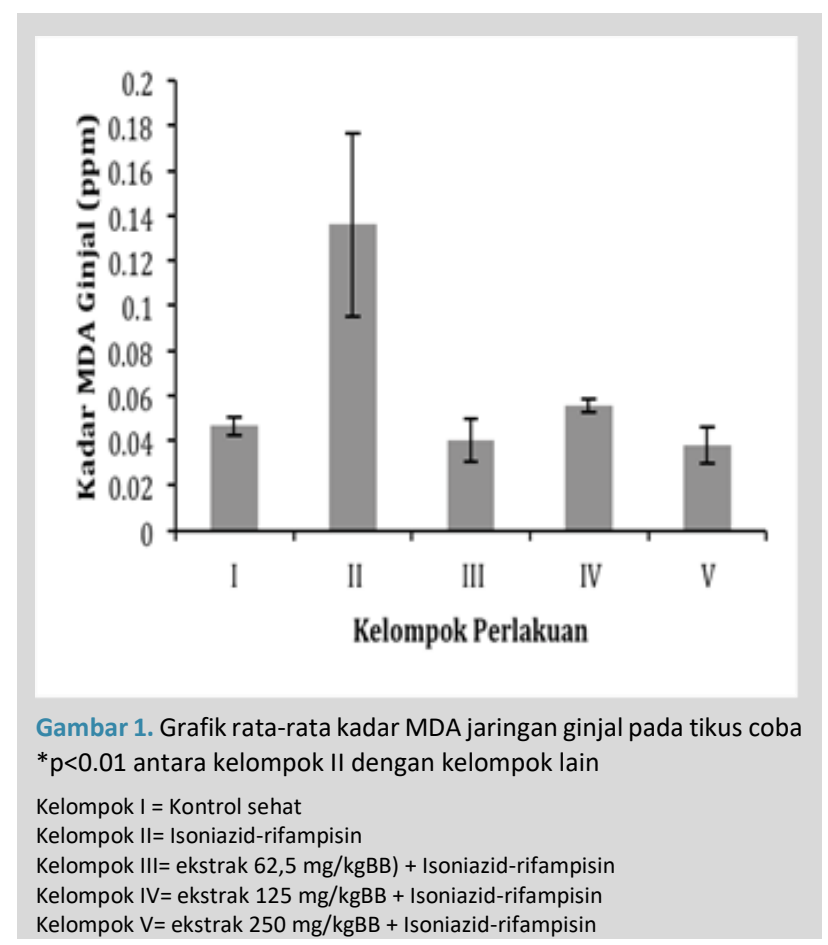

Hasil tersebut mengindikasikan bahwa ekstrak air rosella mampu menurunkan peroksidasi lipid yang disebabkan oleh pembentukan radikal bebas yang diinduksi oleh isoniazidrifampisin. Peningkatan radikal bebas yang terus menerus terjadi akan berakibat sitotoksik sehingga mampu menyebabkan ganguan fungsi hati dan ginjal $(6,11)$. Sebenarnya peningkatan radikal bebas dan stress oksidatif dalam tubuh dapat ditangani dengan peningkatan produksi antioksidan endogen. Namun produksi radikal bebas yang berlebih dan dalam jangka waktu yang lama, sering tidak dapat diimbangi dengan produksi antioksidan endogen yang semakin lama semakin menurun (26). Ekstrak bunga rosella memiliki aktivitas antioksidan yang kuat terhadap oksigen reaktif dan radikal bebas, menghambat aktivitas xantin oksidase, melindungi kerusakan sel dari peroksidasi lipid, menghambat $\mathrm{Cu} 2+$ yang memediasi pembentukan thiobarbituric acid reactive substances (TBARs), meningkatkan aktivitas superoksid dismutase, katalase dan glutathione serta menghambat pembentukan MDA (15).

Bunga rosella (Hibiscus sabradiffa L.) memiliki senyawa yang berpotensi sebagai agen hepatoprotektif dan nefroprotektif. Bunga rosella diketahui memiliki kandungan polifenol, flavonoid dan antosianin, seperti delphinidin-3-0-glucoside, delphinidin-3-0-sambubioside, cyanidin-3-0-sambubioside, asam organik, flavanoid dan polisakarida $(15,27)$. Antosianin dan asam prokatelunat ini memiliki efek antioksidan kuat yang berfungsi secara langsung untuk menghentikan aktivitas radikal bebas yang terbentuk dari metabolisme obat, sehingga dapat mengurangi stress oksidatif dan kerusakan sel serta melemahkan disfungsi mitokondria melalui penurunan ekspresi Bax dan tBid di hati (15).

\section{KESIMPULAN}

Pemberian kombinasi isoniazid dan rifampisin mampu meningkatkan kadar MDA pada jaringan hati dan ginjal. Ekstrak air bunga rosella (Hibiscus sabdariffa L.) 
terenkapsulasi maltodextrin dosis 62.5, 125 dan 250 $\mathrm{mg} / \mathrm{kgBB}$ dapat menghambat peningkatan peroksidasi lipid pada hati dan ginjal tikus wistar jantan yang diinduksi isoniazid-rifampisin dosis toksik.

\section{UCAPAN TERIMA KASIH}

Penulis mengucapkan terima kasih kepada LPDP Indonesia atas bantuan pendanaan. Penulis juga berterima kasih kepada Fakultas Farmasi Universitas Hasanuddin atas dukungan moril dan sarana selama penulis melakukan penelitian.

\section{DAFTAR PUSTAKA}

1. Shang, P., Xia, Y., Liu, F., Wang, X., Yuan, Y., Hu, D., et al. Incidence, clinical features and impact on anti-tuberculosis treatment of anti-tuberculosis drug induced liver injury (ATLI) in China. PLoS One, 2011; 6(7): e21836.

2. Baghaei, P., Tabarsi, P., Chitsaz, E., Saleh, M., Marjani, M., Shemirani, S., et al. Incidence, clinical and epidemiological risk factors, and outcome of drug-induced hepatitis due to antituberculous agents in new tuberculosis cases. American journal of therapeutics, 2010;17(1): 17-22.

3. Khalili, H., Dashti-Khavidaki, S., Rasoolinejad, M., Rezaie, L., and Etminani, M. Anti-tuberculosis drugs related hepatotoxicity; incidence, risk factors, pattern of changes in liver enzymes and outcome. Daru, 2009;17(3)

4. Ohno, M., Yamaguchi, I., Yamamoto, I., Fukuda, T., Yokota, S., Maekura, R. et al. Slow $\mathrm{N}$-acetyltransferase 2 genotype affects the incidence of isoniazid and rifampicin-induced hepatotoxicity. The International Journal of Tuberculosis and Lung Disease,2000; 4(3): 256-261.

5. Askgaard, D.S., Wilcke, T., and Døssing, M. Hepatotoxicity caused by the combined action of isoniazid and rifampicin. Thorax, 1995; 50(2): 213 214.

6. Tafazoli, S., Mashregi, M., and O'brien, P.J. Role of hydrazine in isoniazidinduced hepatotoxicity in a hepatocyte inflammation model. Toxicology and applied pharmacology, 2008; 229(1): 94-101.

7. Yue, J., and Peng, R. Does CYP2E1 play a major role in the aggravation of isoniazid toxicity by rifampicin in human hepatocytes? British journal of pharmacology, 2009' 157(3): 331-333.

8. Fuhr, U. Induction of drug metabolising enzymes. Clinical pharmacokinetics,2000; 38(6): 493-504.

9. Wen, X., Wang, J.-S., Neuvonen, P.J., and Backman, J.T. Isoniazid is a mechanism-based inhibitor of cytochrome P 450 1A2, 2A6, 2C19 and 3A4 isoforms in human liver microsomes. European journal of clinical pharmacology, 2002; 57(11): 799-804.

10. Covic, A., Goldsmith, D., Segall, L., Stoicescu, C., Lungu, S., Volovat, C., et al Rifampicin-induced acute renal failure: a series of 60 patients. Nephrology, dialysis, transplantation: official publication of the European Dialysis and Transplant Association-European Renal Association, 1998;13(4): 924-929.

11. Chowdhury, A., Santra, A., Bhattacharjee, K., Ghatak, S., Saha, D.R., and Dhali, G.K. Mitochondrial oxidative stress and permeability transition in isoniazid and rifampicin induced liver injury in mice. Journal of hepatology, 2006;45(1): 117-126.

12. Pedraza-Chaverri, J., Yam-Canul, P., Chirino, Y.I., Sánchez-González, D.J., Martínez-Martínez, C.M., Cruz, C., et al. Protective effects of garlic powder against potassium dichromate-induced oxidative stress and nephrotoxicity. Food and chemical toxicology, 2008;46(2): 619-627.

13. Lin, H.-H., Chen, J.-H., and Wang, C.-J. Chemopreventive properties and molecular mechanisms of the bioactive compounds in Hibiscus sabdariffa Linne. Current medicinal chemistry, 2011;18(8): 1245-1254.

14. Sarr, M., Ngom, S., Kane, M.O., Wele, A., Diop, D., Sarr, B., et al. In vitro vasorelaxation mechanisms of bioactive compounds extracted from Hibiscus sabdariffa on rat thoracic aorta. Nutrition \& metabolism, 2009;6(1): 45.

15. Da-Costa-Rocha, I., Bonnlaender, B., Sievers, H., Pischel, I., and Heinrich, M. Hibiscus sabdariffa L.-A phytochemical and pharmacological review. Food chemistry,2014; 165: 424-443.

16. Fakeye, T.O., Pal, A., Bawankule, D., Yadav, N., and Khanuja, S. Toxic effects of oral administration of extracts of dried calyx of Hibiscus sabdariffa Linn (Malvaceae). Phytotherapy research, 2009;23(3): 412-416. (16)

17. Djide, M.N., Sartini, Amir., M.N., and Juniarti, N.. Pengembangan Formula Ekstrak Kelopak Bunga Rosella (Hibiscus sabdariffa L.) Terstandar Sebagai Terap Alternatif/Supportif dalam Mengatasi Resistensi Obat Antituberkulosis. (Laporan Penelitian). Makassar: Universitas Hasanuddin.2017

18. Che Man, Y.B., Irwandi, J., and Abdullah, W.J.W. Effect of different types of maltodextrin and drying methods on physico-chemical and sensory properties of encapsulated durian flavour. Journal of the Science of Food and Agriculture,1999; 79(8): 1075-1080.

19. Karumi, Y., Addy, E., and Ugonna, O. The Protective Effect of Aqueous Extract of the Calyx of Hibiscus sabdariffa Roselle on the Kidneys of SaltLoaded Rats. Journal of Medical Laboratory Science, 2013;12(1): 46-52.

20. Nafizah, A.H.N., Budin, S.B., Zaryantey, A.H., Mariati, A.R., Santhana, R.L., Osman, M., et al. Aqueous calyxes extract of Roselle or Hibiscus sabdariffa Linn supplementation improves liver morphology in streptozotocin induced diabetic rats. Arab journal of gastroenterology, 2017;18(1): 1320.

21. Yin, G., Cao, L., Xu, P., Jeney, G., and Nakao, M. Hepatoprotective and antioxidant effects of Hibiscus sabdariffa extract against carbon tetrachloride-induced hepatocyte damage in Cyprinus carpio. In Vitro Cellular \& Developmental Biology-Animal, 2011' 47(1): 10-15.

22. Patel, S. Hibiscus sabdariffa: An ideal yet under-exploited candidate for nutraceutical applications. Biomedicine \& Preventive Nutrition, 2014;4(1): 23-27.

23. Chen, R., Wang, J., Zhang, Y., Tang, S., and Zhan, S. Key factors of susceptibility to anti-tuberculosis drug-induced hepatotoxicity. Archives of toxicology, 2015;89(6): 883-897.

24. Ayala, A., Muñoz, M.F., and Argüelles, S. Lipid peroxidation: production, metabolism, and signaling mechanisms of malondialdehyde and 4 hydroxy-2-nonenal. Oxidative medicine and cellular longevity, 2014.

25. Draper, H., and Hadley, M. [43] Malondialdehyde determination as index of lipid Peroxidation Methods in enzymology, 1990; (Vol. 186, pp. 421431): Elsevier.

26. Cadenas, E., and Davies, K.J. Mitochondrial free radical generation, oxidative stress, and aging1. Free Radical Biology and Medicine, 2000;29(3-4): 222-230.

27. Hopkins, A.L., Lamm, M.G., Funk, J.L., and Ritenbaugh, C. Hibiscus sabdariffa L. in the treatment of hypertension and hyperlipidemia: a comprehensive review of animal and human studies. Fitoterapia, 2013;85: 84-94 